
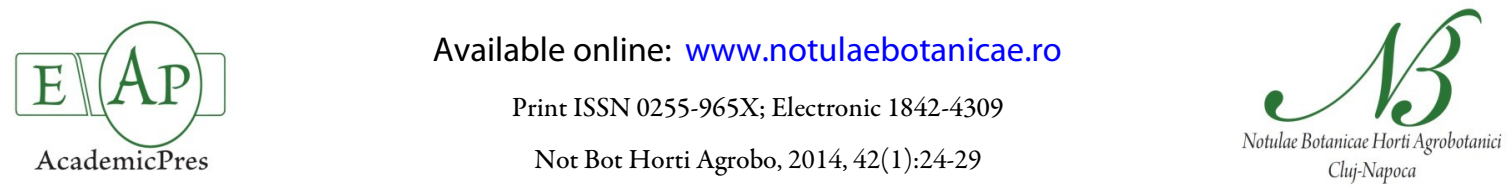

\title{
Phenolic Profile of the Kernel of Selected Persian Walnut (Juglans regia L.) Cultivars
}

\author{
Géza BUJDOSÓ ${ }^{1,2 *}$, György VÉGVÁRI ${ }^{3 *}$, Veronika HAJNAL ${ }^{1}$, Gitta FICZEK ${ }^{1}$, \\ Magdolna TÓTH ${ }^{1}$ \\ ${ }^{1}$ Corvinus University of Budapest, Department of Pomology, 29-43, Villányi út, Budapest, Hungary; geza.bujdoso@uni-corvinus.hu, \\ gitta.ficzek@uni-corvinus.hu,veronika.hajnal@uni-corvinus.hu,magdolna.toth@uni-corvinus.hu \\ ${ }^{2}$ National Agricultural Research and Innovation Centre, Fruitculture Research Institute, 2, Park utca, Budapest, Hungary; resinfru@yahoo.com \\ ${ }^{3}$ Corvinus University of Budapest, Department of Soil Science and Water Management, 29-43, Villányi út, Budapest, Hungary; \\ gyorgy.vegvari@uni-corvinus.hu (*correspondingauthors)
}

\begin{abstract}
The Persian walnut (Juglans regia L.) also known as English, Carpathian or common walnut is an important fruit species for Central and Eastern Europe, as its productivity increases annually due to its good market situation. Phenolic compounds of fifteen Persian walnut cultivars and two selected genotypes were examined by HPLC in this research paper. If we rank the phenolic compounds of the examined cultivars based on their quantity into increasing relative order, the quantity of Vanillic acid was the highest compound followed by Cathechin, Pyrocathechin, Epicathechin, Rutin, Syringic acid, Gallic acid, Juglone and Cinnamic acid. As results it can be considered that the Hungarian bred walnut cultivars had higher phenolic content compared to foreign cultivars. Among foreign bred cultivars evaluated in this paper the Serbian cultivars 'Srem' and 'Sampion' had the best results.
\end{abstract}

Keywords: dried fruit samples, HPLC analysis, Hungarian bred cultivars, Serbian bred cultivars, ten phenolic compounds, US bred cultivars

\section{Introduction}

The Persian walnut (Juglans regia L.) plays an important role within the fruit producing industry of Central and Eastern European countries and the production is increasing yearly because of favourable markets. Ukraine has the largest Persian walnut dried in-shell production in the region with about 80,000 metric tons produced annually, followed by Romania with approximately 35,000 tons, Serbia with more or less 22,000 tons and Hungary with around 5,500 tons (FAO, 2013). The growers in Romania, Serbia and Hungary use state registered cultivars, while the Ukrainian growers mostly collect walnut from the seedling populations.

Walnut growing is a major tree crop in Central Europe with active breeding programs supporting this industry. In Hungary the Persian walnut breeding started at the Fruit Growing Research Institute in 1950, and from this program eight walnut cultivars are registered on the Hungarian National Variety List. In Romania new Persian walnut cultivars were either selected from local populations or by cross breeding (Botu et al., 2010). In Serbia the "breeding" method was through selection by organizing a competition "Searching for quality walnut" (Korac et al., 1986).

The walnut kernel has a high oil content $(45-72 \%$ of the kernel weight), that consists mainly of unsaturated fatty acids. In addition to oil, the kernel contains proteins (13$25 \%$ of the kernel weight), available carbohydrate (4-15\% of the kernel weight), fibre (4.6-7.5\% of the kernel weight), and minerals (1.65-2.4\% of the kernel weight) (Bujdosó et al., 2010; Germain et al., 1999). Studies of Bujdosó et al. (2010) and Solar et al. (2006) on walnut fruit quality concluded that the environment plays a major role to influence the ratio of these compounds of kernels yearly.

In recent studies reports on the phenolic profiles of walnut trees describe the total phenolic content in different parts of walnut, namely, shoots (Cosmulescu and Trandafir, 2011a; Solar et al., 2006), leaves, and the green husk (Cosmulescu and Trandafir, 2011b; Jakopic et al., 2007; Stampar et al., 2006; Cosmulescu and Trandafir, 2012). Some phenolic compounds protect Persian walnut against bacterial and fungal diseases (Mikulic-Petkovsek et al., 2011). Chevallier et al. (2009) stated that flavonoids and hydroxi-cinnamic acid are the main responsible compounds of different walnut cultivars and genotypes susceptibility or tolerance against Xanthomonas arboricola pv. juglandis. Furthermore, the extract of fresh walnut leaves inhibited selectively the growth of Gram positive bacteria (Bacillus cereus, B. subtilis, Staphylococcus aureus), but Gram negative bacteria (Pseudomonas aeruginosa, Escherichia coli, Klebsiella pneumoniae) and fungi (Candida albicans, Cryptococcus neoformans) were resistant to the extract at $100 \mathrm{mg} / \mathrm{mL}$ (Pereira et al., 2007).

The five major phenolic compounds in the walnut kernel are gallic and cinnamic acid, catechin, juglone and rutin. Gallic acid is the most readily bio available compound for the human body, and is followed by cathechin 
(Williamson and Manach, 2007). Cinnamic acid appears to improve glycaemic parameters in diabetic patients suffering from type two diabetes inconsistently (Rudkowska, 2009). A few studies show that juglone has anti-cancer activity against human tumour lines and has anti-cancer effect against chemo/radio resistant melanomas among in vivo conditions (Babich and Stern, 1993; Bonifazi et al., 2010). Rutin has many physiological functions and is known for its anti-oxidant activity (Harborne and Williams, 2000). Other bioactive phenols include vanillic acid, epicathechin, cinnamic acid that are characteristic for higher plants.

The phenolic compounds in the seed coat are higher compared to the walnut flesh. For example, total phenolic content of a dehulled 'Chandler' kernel was $16,300 \mu \mathrm{g} / \mathrm{g}$ in the kernel and $403000 \mu \mathrm{g} / \mathrm{g}$ in the seed coat (Labucas et al., 2008). In addition, Colaric et al. (2005) measured a 38-fold higher phenolic content in the pellicle of 'Alsószentiváni $117^{\prime}(727 \mathrm{mg} / \mathrm{g})$ than in the walnut kernel $(19.16 \mathrm{mg} / \mathrm{g})$, thus the pellicle is much better source of phenolic compounds than the kernel.

This investigation is a follow-up from previous results to refine the analysis of the walnut kernel contents. The aim of the study was to identify and quantify the phenolic compounds in the kernel of a few selected Hungarian, Serbian, US, and French bred walnut cultivars using HPLC.

\section{Materials and methods}

\section{Fruit samples}

The fruit samples were collected in fall of 2012, and Tab. 1 shows the walnut cultivars with their most important characteristics included in this study. Fruit of the eight state registered Hungarian bred Persian walnut cultivars ('Alsószentiváni 117', 'Milotai 10', 'Tiszacsécsi 83', 'Milotai bőtermő', 'Milotai kései', 'Milotai intenzív', 'Bonifác', 'Alsószentiváni kései') and two selected genotypes (BD06, red kernel genotype) were examined in the trial. Fruit of state registered cultivars and selected genotypes were collected from experimental orchards of the NARIC Fruitculture Research Institute (average annual sunshine hours are 2,094 hours, average annual temperatures are 11.1 ${ }^{\circ} \mathrm{C}$, average annual precipitation is $560 \mathrm{~mm}$, type of the soil is Chernozem soil $\mathrm{Ka}=40, \mathrm{pH}=8$, lime content $5 \%$, humus content $2.3 \%$ ).

Fruit samples of the American bred 'Chandler', and 'Hartley' and the French bred 'Fernor' cultivars were collected at Juglans Hungaria Ltd. in Lengyeltóti (Hungary) (average annual sunshine hours are 2,098 hours, average annual temperatures are $11.2{ }^{\circ} \mathrm{C}$, average annual precipitation is $550 \mathrm{~mm}$, type of the soil is Chernozem soil $\mathrm{Ka}=38, \mathrm{pH}=8$, lime content $5 \%$, humus content $1.9 \%$ ). The Serbian bred cultivars were grown near Senta (Serbia) (average annual sunshine hours are 2,104 hours, average annual temperatures are $11.5{ }^{\circ} \mathrm{C}$, average annual precipitation is $580 \mathrm{~mm}$, type of the soil is Chernozem soil $\mathrm{Ka}=42, \mathrm{pH}=7.5$, lime content $2.5 \%$, humus content $2.0 \%$ ).

In order to analyze the chemical content of the fruit, the husks were removed immediately after the harvest. The samples were washed and dried up to $10 \%$ of moisture content and were stored as a walnut in its shell at $+8{ }^{\circ} \mathrm{C}$ until further processed in the laboratory. The harvest time was when $50 \%$ of husks had been opened.

\section{Chemicals}

Analytical HPLC grade standards of different phenolic compounds such as juglone [481-39-0], gallic acid [149-917], chlorogenic acid [327-97-9], pyrocatechin [120-80-9], catechin [154-23-4], syringic acid [530-57-4], rutin [15318-4], cinnamic acid [140-10-3], epicathechin [154-234-], vanillic acid [121-34-6], and the solvents phosphoric acid and methanol $(\mathrm{MeOH})$, were purchased from Sigma Aldrich Chemical Co. (St. Louis, MO, USA). The standards $(0.5 \mathrm{~g} / \mathrm{ml})$ were dissolved in methanol and a $100 \times$ dilution was used as the working standard for HPLC.

Tab. 1. Walnut cultivars and genotypes ${ }^{*}$ included in the research

\begin{tabular}{|c|c|c|c|c|c|}
\hline Cultivar & Origin & $\begin{array}{l}\text { Ripening time } \\
\text { (in decade) }\end{array}$ & $\begin{array}{c}\text { Fruit size } \\
(\mathrm{mm})\end{array}$ & $\begin{array}{c}\text { Kernel } \\
\text { ratio (\%) }\end{array}$ & Kernel colour \\
\hline ‘Alsószentiváni 117’ & Open-pollinated selection from Hungary & IX. $1^{\text {st }} \mathrm{d}$ & $33-36$ & 50 & Light brown \\
\hline 'Milotai 10’ & Selection from Hungarian population & IX. $2^{\text {nd }} \mathrm{d}$ & $32-34$ & 48 & Yellowish brown \\
\hline ‘Tiszacsécsi 83’ & Selection from Hungarian population & IX. $3^{\text {rd }} \mathrm{d}$ & $32-34$ & 50 & Yellowish brown \\
\hline 'Milotai bőtermő' & 'Milotai 10' x 'Pedro', Hungary & $X .1^{\text {st }} \mathrm{d}$ & $34-36$ & 49 & Yellowish brown \\
\hline 'Milotai intenzív' & 'Milotai 10' x 'Pedro', Hungary & IX. $3^{\text {rd }} \mathrm{d}$ & $32-34$ & 52 & Yellowish brown \\
\hline 'Milotai kései' & 'Milotai 10' x 'Pedro', Hungary & $X .1^{\text {st }} \mathrm{d}$ & $32-34$ & 44 & Light brown \\
\hline 'Bonifác' & ‘A 117’x x 'Pedro', Hungary & $X .1^{\text {st }} \mathrm{d}$ & $32-34$ & 46 & Light brown \\
\hline 'Alsószentiváni kései' & 'A 117 ' x 'Pedro' Hungary & $X .1^{\text {st }} \mathrm{d}$ & $32-34$ & 48 & Yellowish brown \\
\hline 'BD06* & Selection from Hungarian population & IX. $1^{\text {st }} \mathrm{d}$ & $32-34$ & 46 & Yellowish brown \\
\hline Red kernel genotype* & Selection from Hungarian population & IX. $3^{\text {rd }} \mathrm{d}$ & 32 & 44 & Red \\
\hline 'Chandler' & 'Pedro' x 'UC 56-224' (bred in USA) & IX $3^{\text {rd }} \mathrm{d}$ & $28-30$ & 49 & Light brown \\
\hline 'Fernor' & 'Franquette' x 'Lara' (bred in France) & $X .1^{\text {st }} \mathrm{d}$ & $31-34$ & $40-44$ & Yellowish brown \\
\hline 'Hartley' & Landscape selected from Napa Valley (USA) & $X .2^{\text {nd }} d$ & $28-30$ & 42 & Yellowish brown \\
\hline 'Sampion' & Selection from Serbian population & X. $2^{\text {nd }} d$ & $32-34$ & 58 & Light brown \\
\hline 'Srem & Selection from Serbian population & $X .2^{\text {nd }} d$ & $32-34$ & 57 & Light brown \\
\hline
\end{tabular}

Sources: Szentiványi, 2006; Cerovic et al., 2010; Hendricks et al., 1998. 


\section{Preparation of samples}

Whole kernels with their seed coats $(1000 \mathrm{~g})$ were used as starter material and $1 \mathrm{~g}$ samples were extracted in $10 \mathrm{ml}$ methanol for 12 hours in the dark at $4{ }^{\circ} \mathrm{C}$, using an Edmund Bühler SM 30 control shaker $(200 \mathrm{rpm} / \mathrm{min})$. The supernatant was decanted and centrifuged in Eppendorf tubes in a Hettich Mikro 22R centrifuge $(15000 \mathrm{rpm} / \mathrm{min}$ for $5 \mathrm{~min})$. The supernatant was filtered on a $0.45 \mu \mathrm{m}$ MILLEX -HV Syringe Driven Filter Unit (SLHV 013 NL, PVDF Durapore), purchased from Millipore Co. (Bedford, MA, USA), and injected into the HPLC system. The quantities of the individual phenolic compounds are given in $\mu \mathrm{g} / \mathrm{g}$.

\section{HPLC conditions}

The WATERS High Performance Liquid Chromatograph (Waters Co., 34 Maple Street, Milford, MA, USA) was equipped with an absorbance detector (2487 Dual $\lambda$ ), a binary HPLC pump (1525), and in-line degasser, a column thermostat (set at $40^{\circ} \mathrm{C}$ ) and an 717 plus auto sampler (set at $5{ }^{\circ} \mathrm{C}$ ) and was controlled using EMPOWERTM2 software. A KINETEX C18 2.6um $150 \times 4.6 \mathrm{~mm}$ column (Phenomenex $411 \mathrm{Madrid}$ Avenue Torrance, CA 90501-1430 USA) was installed, and the gradient mobile phase was $\mathrm{A}$ : $\mathrm{H}_{2} \mathrm{O}: \mathrm{MeOH}$ : $\mathrm{H}_{3} \mathrm{PO}_{4}=940: 50: 1, \mathrm{~B}: \mathrm{MeOH}$ (0-30 min: A 100\%-10\%, 3030.1 min: $10 \%-100 \%, 30.1-31$ : A $100 \%)$ with a flow rate 1 $\mathrm{cm}^{3} / \mathrm{min}$, the pressure in the column was $4200 \pm 10$ psi at a column temperature of $30^{\circ} \mathrm{C}$. The running time was 22 minutes. Each injected volume was $20 \mu \mathrm{l}$.

The sampling rate was $10 \mathrm{pt} / \mathrm{sec}$, and the phenolic components were monitored at a wavelength of $280 \mathrm{~nm}$ (gallic acid, pyrocatechin, catechin, syringic acid, rutin, cinnamic acid, vanillic acid, epicathechin) and $350 \mathrm{~nm}$ (juglone). The retention times of the standards were gallic acid (7.7 min), pyrocatcechin $(7.5 \mathrm{~min})$, cathechin $9.6 \mathrm{~min}$, chlorogenic acid $(11.4 \mathrm{~min})$, vanillic acid $(11.8 \mathrm{~min})$, epicatchechin (12.7 min), syringiyc acid (12.9 min), rutin (18.5 min), juglone (20.6 min) and cinnamic acid (21.6 min) respectively.

\section{Statistical analysis}

Three replicates were made in all cases. The statistical analysis was performed using PASW STATISTICS 18.0. Univariate analysis was carried out to separate the homogeneous groups using Duncan's test. The RSD value of the determination was $5 \%(n=5)$. The results were expressed as $\mu \mathrm{m}$ of $1 \mathrm{~g}$ of dried weight kernel.

\section{Results and discussions}

The phenolic compound profiles of the fifteen tested walnut cultivars are shown in Figs. 1 to 9. Six of the nine tested phenolic compounds were present in all fifteen cultivars, and varied in their concentration levels. The phenolic compounds not present in all the cultivars are catechin (Fig. 3), vanillic acid (Fig. 4), epicatechin (Fig. 5) and chlorogenic acid (not shown). The gallic acid concentration was outstandingly high in 'Milotai bötermo"

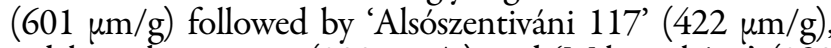
red kernel genotype $(399 \mu \mathrm{m} / \mathrm{g})$ and 'Milotai kései' (380 $\mu \mathrm{m} / \mathrm{g})$. 'Hartley' $(37 \mu \mathrm{m} / \mathrm{g})$ and 'Milotai intenzív' $(51 \mu \mathrm{m} / \mathrm{g})$ had the lowest gallic acid content (Fig. 1).

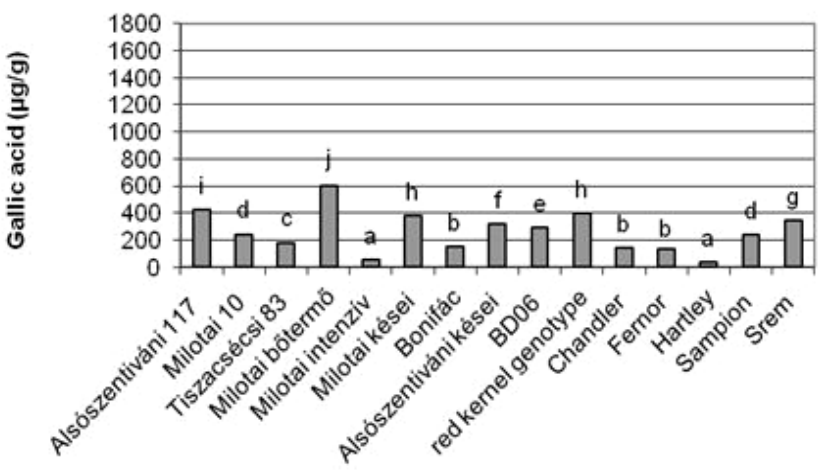

Fig. 1. Gallic acid content of kernels in analysed cultivars $\left(\mathrm{SD}_{5 \%}=70\right)$

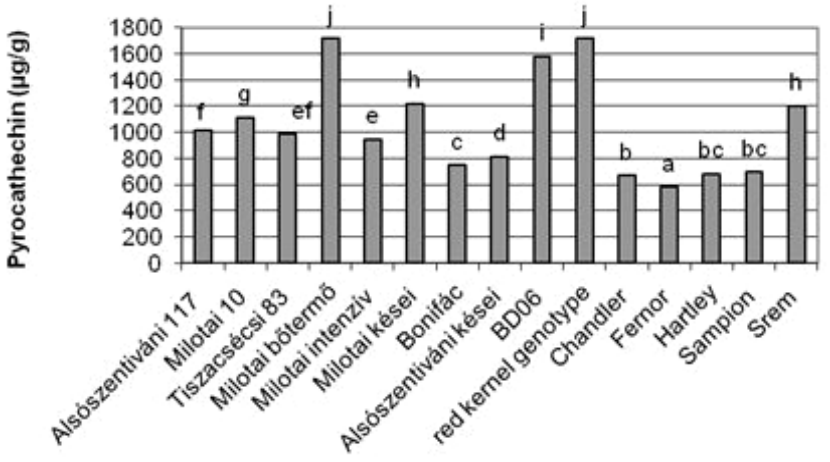

Fig. 2. Pyrocathechin content of kernels in analysed cultivars $\left(\mathrm{SD}_{5 \%}=58\right)$

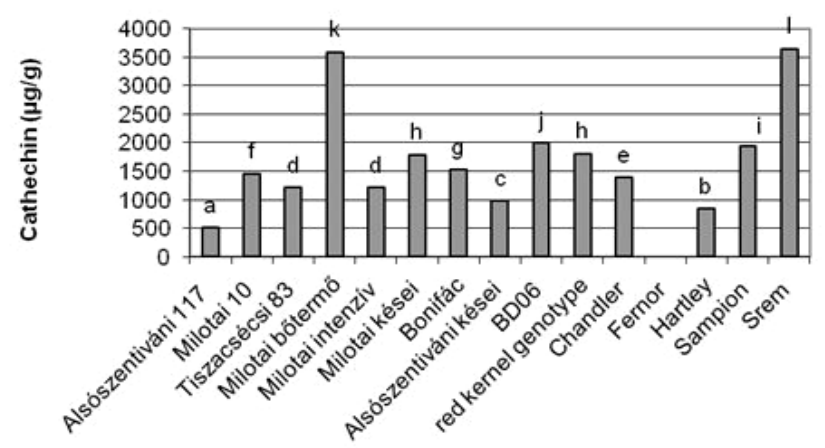

Fig. 3. Cathechin content of kernels in analysed cultivars $\left(\mathrm{SD}_{5 \%}=212\right)$

Red kernel genotype $(1,717 \mu \mathrm{m} / \mathrm{g})$, 'Milotai bőtermő' $(1,715 \mu \mathrm{m} / \mathrm{g})$ and 'BD06' $(1,580 \mu \mathrm{m} / \mathrm{g})$ genotype had the largest pyrocathecin concentration in our trial; the lowest ones were produced by foreign bred cultivars except 'Srem' (1 $202 \mu \mathrm{m} / \mathrm{g}$ ) (Fig. 2).

The Serbian bred 'Srem' (3 $646 \mu \mathrm{m} / \mathrm{g}$ ) and the Hungarian bred 'Milotai bőtermo"' (3 $587 \mu \mathrm{m} / \mathrm{g}$ ) had 2 to 7 fold higher cathechin content compared to other Persian walnut cultivars examined in the trial. Cathechin content was not present in French bred 'Fernor' (Fig. 3).

Chlorogenic acid content was also examined in the samples but red kernel genotype contained this compound only, which quantity was equal to $428 \mathrm{\mu g} /$ of kernel.

Both Serbian bred cultivars ('Srem', 'Sampion'), 'Bonifác', 'Milotai kései' and 'Milotai intenzív' had Vanillic acid content among examined samples. 'Srem' had an 


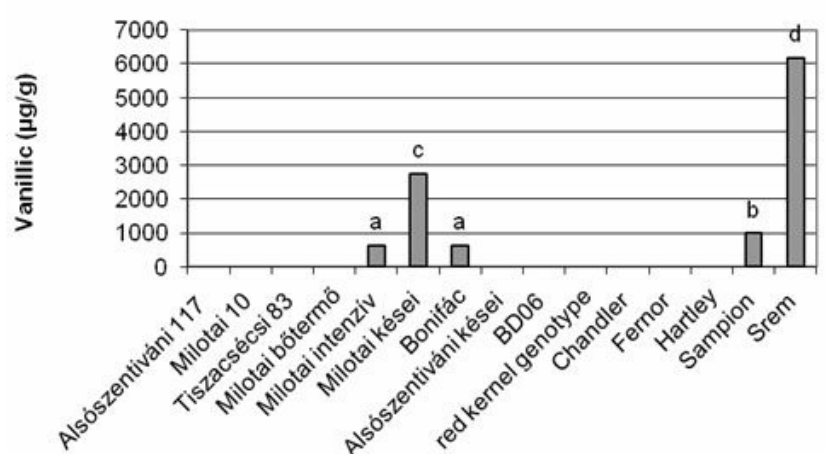

Fig. 4. Vanillic acid content of kernels in analysed cultivars $\left(\mathrm{SD}_{5 \%}=256\right)$

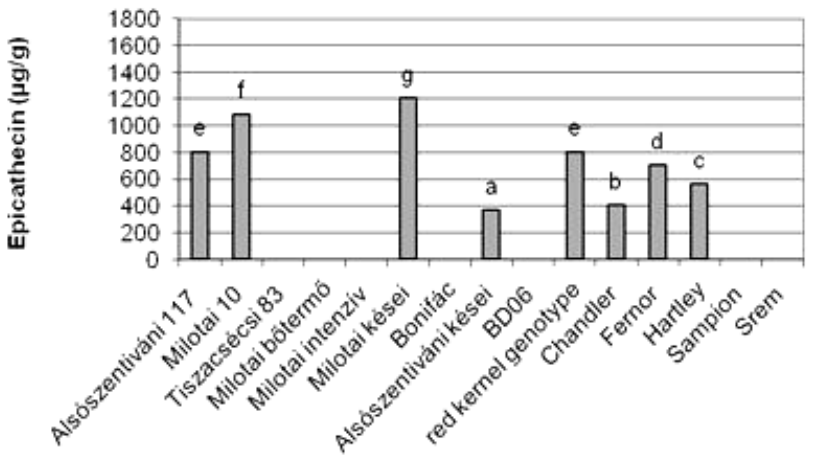

Fig. 5. Epicathechin content of kernels in analysed cultivars $\left(\mathrm{SD}_{5 \%}=38\right)$

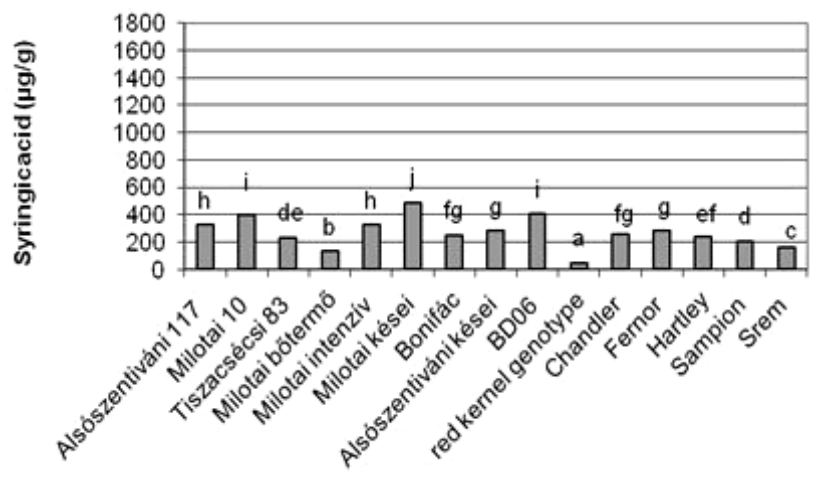

Fig. 6. Syringic acid content of kernels in analysed cultivars $\left(\mathrm{SD}_{5 \%}=70\right)$

outstanding Vanillic acid content, which was higher with $130 \%$ compared to 'Milotai kései' ranked on second place. The Vanillic acid content of other cultivars was equal or lower to $1 \mu \mathrm{g} / \mathrm{g}$ of kernel (Fig. 4).

Eight samples contained epicathechin among fifteen involved in the trial. 'Milotai kései' had the highest epicathechin content $(1.20 \mu \mathrm{m} / \mathrm{g})$ followed by 'Milotai 10 ' (1 $088 \mu \mathrm{m} / \mathrm{g}$ ) and 'Alsószentiváni 117' (807 $\mu \mathrm{m} / \mathrm{g})$. Lower than $1 \mu \mathrm{g} / \mathrm{g}$ epicathechin content was measured in the kernel of the Serbian bred Persian walnut cultivars (Fig. 5).

The highest syringic acid content was in 'Milotai kései' $(489 \mu \mathrm{m} / \mathrm{g})$ followed by BD06 $(405 \mu \mathrm{m} / \mathrm{g})$ and 'Milotai 10' $(399 \mu \mathrm{m} / \mathrm{g})$. The red kernel genotype $(48 \mu \mathrm{m} / \mathrm{g})$ had the lowest syringic acid content (Fig. 6).

The highest juglone content was measured in 'Srem' $(285 \mu \mathrm{m} / \mathrm{g})$ followed by 'Alsószentiváni 117’ $(235 \mu \mathrm{m} / \mathrm{g})$



Fig. 7. Juglone content of kernels in analysed cultivars $\left(\mathrm{SD}_{5 \%}=22\right)$

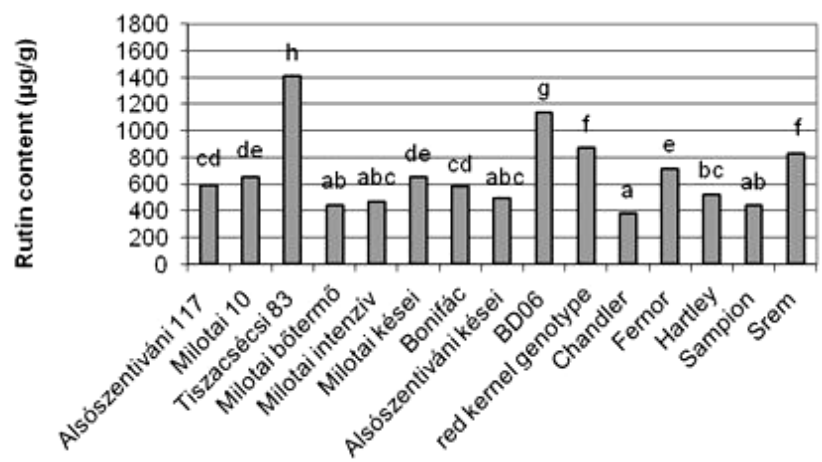

Fig. 8. Rutin content of kernels in analysed cultivars $\left(\mathrm{SD}_{5 \%}=52\right)$

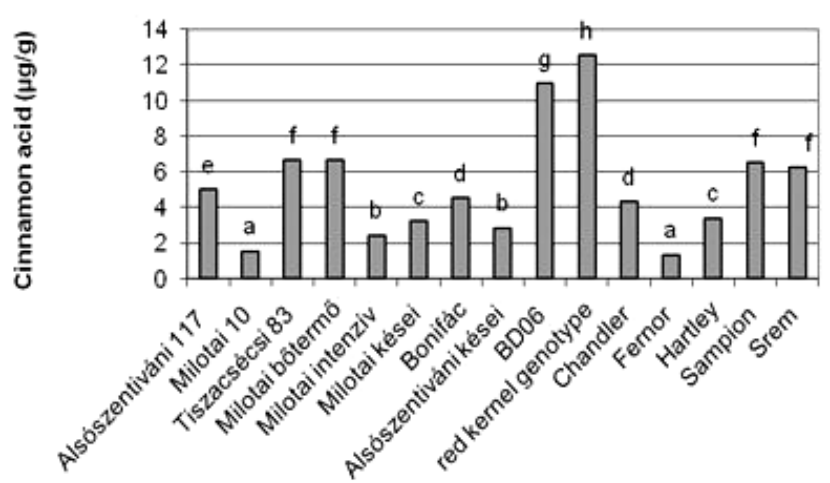

Fig. 9. Cinnamic acid content of kernels in analysed cultivars $\left(\mathrm{SD}_{5 \%}=0.46\right)$

and red kernel genotype $(212 \mu \mathrm{m} / \mathrm{g})$. The lowest juglone concentration was detected in 'Hartley' $(31 \mu \mathrm{m} / \mathrm{g})$ and 'Milotai bőtermő' (27 $\mu \mathrm{m} / \mathrm{g})$ (Fig. 7).

'Tiszacsécsi 83' (1 $407 \mu \mathrm{m} / \mathrm{g})$, BD06 (1 $141 \mu \mathrm{m} / \mathrm{g})$, red kernel genotype $(874 \mu \mathrm{m} / \mathrm{g})$ and 'Srem' $(826 \mu \mathrm{m} / \mathrm{g})$ had outstanding rutin content, these taxons had almost double rutin concentration than the other cultivars. Beside the named cultivars, 'Srem' (826 $\mu \mathrm{m} / \mathrm{g}$ ) and 'Fernor' (718 $\mu \mathrm{m} / \mathrm{g}$ ) had high rutin content. 'Chandler' (381 $\mu \mathrm{m} / \mathrm{g})$, 'Milotai intenzív' ( $471 \mu \mathrm{m} / \mathrm{g}$ ) and 'Milotai bötermö' (441 $\mu \mathrm{m} / \mathrm{g}$ ) had the lowest content (Fig. 8).

The highest cinnamic acid was produced by the red kernel genotype $(12 \mu \mathrm{m} / \mathrm{g})$ followed by BD06 $(11 \mu \mathrm{m} / \mathrm{g})$ and Serbian bred cultivars, 'Milotai bőtermo"' $(6 \mu \mathrm{m} / \mathrm{g})$ and 'Tiszacsécsi 83' (6 $\mathrm{m} / \mathrm{g})$ (Fig. 9).

There are few results available on the phenolic contents 
28

of walnut kernel available in literature. The quantity in the phenolic compounds of Chinese genotypes, reported by Zhang et al. (2009), is equal or higher compared to the values of the Hungarian bred walnut cultivars. In retrospect, the Hungarian bred cultivars had higher levels of phenolic compounds compared to the Serbian, French and USA bred ones. The reason of this phenomenon may be the poor adaptation of Persian walnut to the different climate conditions, varying from their origin. From this study it was found that the Serbian bred 'Srem' was the only cultivar with high phenolic contents because its cathecin, vanillic acid, rutin and juglone values were almost the highest among the examined cultivars. This is better than for 'Sampion', the second Serbian cultivar reported by Solar et al. (2005) for its high phenolic contents in its kernel.

If the phenolic compounds are ranked according to their quantity, vanillic acid was the highest followed by cathechin, pyrocathechin, epicathechin, rutin, syringin acid, gallic acid, juglone and cinnamic acid in sequential decreasing order. Christopoulos et al. (2010) and Miltiadis et al. (2012) reported that vanillic acid was present in 'Franquette' but at lower levels than found in this study. In our research only five ('Milotai intenzív', 'Milotai kései', 'Bonifác', 'Srem' and 'Sampoin') of the fifteen cultivars contained vanillic acid. Christopolous et al. (2010) reported that the syringic acid content of 'Franquette' at lower levels than some of the Hungarian bred cultivars ('Milotai 10', BD06, 'Milotai kései'). Colaric et al. (2005) detected more juglone content in kernel of 'Alsószentiváni 117' than the other nine examined cultivars ('Adams', 'Cisco', 'Chandler', 'Elit', 'Fernette', 'Fernor', 'Franquette', 'Lara', 'Rasna'). In the cited research 'Alsószentiváni 117’ had 727,000 $\mu \mathrm{m} / \mathrm{g}$ of kernel juglone in the pellicle and $19,160 \mu \mathrm{m} / \mathrm{g}$ of kernel in the walnut flesh; both data were much more higher than measured in our study $(235 \mu \mathrm{m} / \mathrm{g}$ of kernel). Labuckas et al. (2008) confirmed that 'Franquette' had a higher total phenolic content compared to 'Chandler'.

\section{Conclusions}

It is clear that this study shows that walnut kernels of Hungarian bred cultivars contain high phenolic content levels. These results are from one year of study. Therefore, more replications are required from another few years of study to provide better information of the Persian walnut cultivars. The phenolic compounds content is linked with susceptibility to different diseases and should be studied in more detail. According to our results genetic clarification of examined Persian walnut genotypes needs to be checked in the near future.

\section{Acknowledgement}

Our research was supported by TÁMOP 4.2.1./B09/01/KMR/2010-0005 project.

\section{References}

Babich H, Stern A (1993). In vitro cytotoxicities of 1,4naphthoquinone and hydroxylated 1,4-naphthoquinones to replicating cells. J Appl Toxicol 13:353-358.
Bonifazi EL, Ríos-Luci C, León LG, Burton G, Padrón JM, Misico RI (2010). Antiproliferative activity of synthetic naphthoquinones related to lapachol. First synthesis of 5hydroxylapachol. Bioorg Med Chem 18:2621-2630.

Botu M, Tudor M, Botu I, Cosmulescu S, Papachatzis A (2010). Evaluation of walnut cultivars in the conditions of the Oltenia's hill area regarding functioning potential. Annals of the University of Craiova, the series Biology, Horticulture, Food Produce Processing Technology, Environment Engineering XV (XLXI):94-103.

Bujdosó G, Tóth-Márkus M, Daood HG, Adányi N, Szentiványi P (2010). Fruit quality and composition of Hungarian bred walnut cultivars. Acta Aliment 1(39):35-47.

Cerovic, S, Golosin, B, Ninic, Todorovic, J, Bijelic, S, Ognanos, V (2010). Walnut (Juglans regia L.) selection in Serbia. Hort Sci (Prague) 37(1):1-5.

Chevallier A, Bray O, Prunet JP, Giraud M (2009). Factors influencing walnut blight symptoms emergence and development. Acta Hort 861:473-478.

Christopoulos MV, Tsantili E, Papageorgiou V, Komaitis M, Rouskas D (2010). Effects of package atmosphere and temperature on phenolics, total antioxidant capacity and colour in kernels of 'Franquette' walnuts during 8-month storage. Acta Hort 858:75-81.

Colaric M, Veberic R, Solar A, Hudina M, Stampar F (2005). Phenolic acids, syringaldehide, and juglone in fruits of different cultivars of Juglans regia L. J Agric Food Chem 53:6390-6396.

Cosmulescu S, Trandafir I (2011a). Variation of phenols content in walnut (Juglans regia L.). South Western Journal of Horticulture, Biology and Environment 1(2):25-33.

Cosmulescu SN, Trandafir I (2011b). Seasonal variation of total phenols in leaves of walnut (Juglans regia L.). J Med Plants Res 5(19):4938-4942.

Cosmulescu S, Trandafir I (2012). Anti-oxidant activities and total phenolics content of leaf extracts from 14 cultivars of walnut (Juglans regia). J Hortic Sci Biotech 87(5):504-508.

Food and Agriculture Organization of the United Nations (webpage accessed: $7^{\text {th }}$ February 2013).

Germain E, Prunet JP, Garcin A (1999). Le noyer. Ctifl, Paris, 26 p.

Harborne T, Williams A (2000). Advances in flavonoid research since 1992. Phytochemistry 55:481-504.

Hendricks E, Coates L, William W, Elkins B Rachel, McGranahan HG, Phillips, Herb A, Ramos E, Reil D, Wilbur O, Snyder RG (1998). Selection of varieties. In: Ramos, E. David (ed.). Walnut production manual University of California, Oakland 84-89.

Jakopic J, Colaric M, Verebic R, Hudina M, Solar A, Stampar F (2007). How much do the cultivar and preparing time influence the phenolics content in walnut liqueur? Food Chem 104:100-105.

Korac M, Slovic D, Rudic M, Cerovic S, Golosin B (1986). 
Rezultati hibridizacije i selekcije oraha $\mathrm{Na}$ Poljoprivrednom fakultetu u Novom Sadu. Proceedings of the Yugoslav Symposium on the Selection and Breeding of Fruit, Cacak 100-107.

Labuckas DO, Maestri DM, Perelló M, Martinez LM, Lamarque AL (2008). Phenolics from walnut (Juglans regia L.) kernels: Antioxidant capacity and interactions with proteins. Food Chem 107(2):607-612.

Mikulic-Petkovsek M, Slatnar A, Verebic R, Stampar F, Solar A (2011). Phenolic response in green walnut husk after infection with bacteria Xanthomonas arboricola PV. Juglandis. Physiol Molecul Plant Pathol 3-4(76):159-165.

Miltiadis V, Christopoulos MV, Tsantili E (2012). Storage of fresh walnuts (Juglans regia L.)-Low temperature and phenolic compounds. Postharvest Biol Tec 73:80-88.

Pereira JA, Oliveira I, Sousa A, Valentao P, Andrade PB, Ferreira ICFR, Ferreres F, Bento A, Seabra R, Estevinho L (2007). Walnut (Juglans regia L.) leaves: Phenolic compounds, antibacterial activity and antioxidant potential of different cultivars. Food Chem Toxicol 11(45):2287-2295.
Rudkowska I (2009). Functional food for health: Focus on diabetes. Maturitas 3(62):263-269.

Solar A, Colaric M, Hudina M, Stampar F (2005). Phenolic content of walnut fruit as affected by cultivars and developmental stage. Acta Hort 705:231-240.

Solar A. Colaric M, Usenik V, Stampar F (2006). Seasonal variations of selected flavoniods, phenolic acids and quinines in annual shoots of common walnut (Juglans regia L.). Plant Sci 170(3): 453-461.

Stampar F, Solar A, Hudina M, Verebic R, Colaric M (2006). Traditional walnut liquere cocktail of phenolics. Food Chem 4(95): 627-631.

Szentiványi P (2006). Diónemesítés és fajtakutatás [Walnut breeding and variety research]. In. Szentiványi P.-Kállay T. -né (eds.): Dió [Walnut]. Mezőgazda Kiadó, Budapest 60-65.

Williamson G, Manach C (2007). Bioavailability and bioefficacy of polyphenols in human: II. Review of 93 intervention studies. Am J Clin Nut 81:243-255.

Zhang Z, Liao L, Moore J, Wu T, Wang Z (2009). Antioxidant phenolic compounds from walnut kernels (Juglans regia L.). Food Chem 113(1):160-165. 